\author{
Marta Rakoczy* \\ University of Warsaw
}

\title{
TEXT, WRITING, SCHOOL IN ANTHROPOLOGICAL PERSPECTIVE
}

\begin{abstract}
This paper attempts to reveal anthropological structures in the following categories: text and writing; the categories that nowadays require cultural, historical and institutional relativization. The paradigm being maintained is that writing is a mental, individualistic creation and a freely chosen way of life which is a result of late modernity. Moreover, even today it is not the only paradigm and nor is it universally acceptable. This is emphasized and developed upon in the text by using examples from current school exercise books. School - as the main institution of literate initiation, where one experiences one'sfirst mass contact with literature - is an institution in which the practice of writing is regulated by school breaks and is specifically managed for capitalist society's dual division of time. Writing is specifically a tool which is a well-defined, perceptual and social discipline. However, this discipline does not exclude creativity, as long as we go by its late-modern definition.
\end{abstract}

Key words: text and writing, anthropological perspective, school, creation, exercise books

What we understand first in discourse, as Paul Ricoeur wrote in reference to Heidegger's Being and Time, is not another person, but a "pro-ject, that is, the outline of a new way of being in the world. Only writing [...] in freeing itself, not only from its author and from its original audience, but from the narrowness of the dialogical situation, reveals this destination of discourse as projecting the world (Paul Ricoeur 1976: 37). Writing as technology, as Walter J. Ong wrote, „is utterly invaluable and indeed essential for the realization of Fuller, interior, human potentials" [...] Writing heightens consciousness. [...] The use of technology can enrich the human psyche, enlarge the human spirit, intensify its interior life (Ong 1991: 82-83).

* Faculty of Polish Studies, Univeristy of Warsaw, ul. Krakowskie Przedmieście 26/28, 00-927 Warsaw e-mail: marta.rakoczy@wp.pl 
Both cited authors have had a distinct impact on both literary studies and the theory of literacy as treated as a crucial medium for Western modernity. Both of them were zealous apologists of cultural institutions such as philosophy and literature, whose modern forms have had a decisive impact on their understanding of writing. In this article, it is argued that their understanding of writing as a creative and individualistic activity, enabling one to work in a new and more conscious way in cultural reality, and taking place between the disembodied text and the equally disembodied mind, demands relativization. This understanding is rather a result of historically and socially specific cultural conditions rather than a recognition of the very nature of writing. Therefore the aim is to examine the problems of Ricoeur's and Ong's phenomenology of writing. And consequently, to outline new, non-essentialist ways of regarding the relationship between writing, creativity and experience.

In order to bring out the relationship between writing, creating and experience, a relationship that cannot be subjected to any essentialist characteristics, it is necessary to take an anthropological examination of different practices of writing, especially their institutional, spatial, temporal and physical contexts. To put it more specifically, it is essential to begin a debate over school literate practices, practices that enable one to see in writing something more than free creativeness based on the work of an individual mind. Of course, if seen from the perspective of a participant of contemporary culture, writing texts is often associated with creativeness and a freely chosen way of life; with literary and non-literary practices, such as writing blogs, tweets or drawing graffiti. This connection is reflected in dictionaries of contemporary Polish, in which writing is defined primarily as "forming, recognizing their thoughts in writing", "communicating" as well as "creating", recording in writing literary, scientific works, composing". Only one of the four meanings mentioned these days by the dictionaries refers to the materiality and corporeality of writing, defining writing as: "plotting on paper or other material of graphic characters by hand or by copying them with machines". Others define writing by making a reference to its mental or "creative" correlates, associated with a particular communication effect, including in particular the creation of "scientific or literary works" that in the western world establishes writing as a subject of remarkable cultural ennoblement (Mały Słownik Języka Polskiego 1996: 626). In other words, writing is understood as primarily an individualistic and mental activity. The labor of an individual's mind is bound mainly with institutions in the arts and sciences, and is regarded as a prerequisite for any creativity. 
It should be noticed that contemporary definitions of the word "write", in contrast to older ones, clearly separate writing from drawing. According to today's linguistic intuitions, the first one is rather opposed to the old sense of the verb "write", namely "to paint, draw, decorate with colorful strips-characters" (Bankowski 2000: 587). What becomes the medium for formation of thought as well as for communication and literate creativity are words deposited in a series of characters, but not in a line, a shape, color or a hand gesture. The very act of writing is denoted as a disembodied action which happens between an individual's mind, words and a graphic mark, whose materiality is clearly marginalized. A similar elimination of physicality and materiality occurs in terms of definitions of writing, which state, for instance, that the latter is "a form of human communication by means of a set of visible marks related, by convention, to some particular, structural level of language" (http://www.britannica.com/search?query=writing, 20.02.14) or "a system of signs, used for preserving or replacing spoken language by writing" (Encyklopedia PWN 1985: 548). Writing is reduced therefore to specific content and is specific, it is detached from body and matter, it is visual and clear. To the same extent the separation from bodily and material practices develops "text" which is defined by modern dictionaries as "the verbal content of any oral or written statements" (Mały Słownik Języka Polskiego 1996: 935).

Such a conceptualization of writing is the result of a long and varied cultural evolution but is dependent on cultural background. In order to illustrate the fact, it is useful to recall André Leroi - Gourhan, who, in contrast to literacy theorists such as Walter J. Ong, analyzed the origins of alphabetic writing not so much in terms of creation of the most economical system of representation, a system which allows, like other writing systems, to create "texts" in today's meaning of the word, as in terms of abandonment of the bodily and non-verbal specificity of prehistoric graphism. The latter, involving, inter alia, paintings on a rock, incisions on objects, as Leroi-Gourhan claimed in Le Geste et la parole, was based on a completely different form of alphabetic writing, which was radiant, non-linear and consisted of the rhythmic organization of meanings (Leroi - Gourhan 1964-1965). It was not an "autonomous discourse" in the sense employed by Ong, not a text equipped with meaning irrespective of the context of its implementation. It was not a text at all, but a trace of action, a phenomenon, whose culmination was a process which comprehensively involved a human being, rather than its intellectual and communicative effect.

Graphism, it should be added, subsequently originated in western culture. The separation of writing and drawing were extraneous to each 
other; separation which is still absent in the cultures of the Far East, where both actions, as Tim Ingold notes in the book Lines. A Brief History, used the same materials and similar criteria for evaluation (Ingold 2007: 131-136). The fact that there was no clear distinction between these actions was the cause, according to Leroi - Gourhan, of the fact that graphism was independent with respect to verbal language, breaking through its limitations as a tool of expression. Expression, which was not identified with the expression of thought, but with the medium of overall, cognitive, emotional and bodily experience as an alternative to the symbolism of speech. Indeed, relationships between thoughts and words and words and graphic signs, as we know already from the works of Lev Vygotsky, are not universal and all the more they are not innate (Vygotsky 1989: 407). They have a cultural character and this means that they are subjected to historical and social programming.

In other words, the changing of historical, cultural and institutional contexts allows one to see the specificity of the modern conceptualization of "writing" and "text". This means that the category of creativity is itself poblematic. As noted by Elisabeth Hallam and Tim Ingold in the introduction to the book Creativity and Cultural Improvisation, categorization currently prevails as part of the global consumption market where creativity "begins to be seen as the main driving force of economic growth and social well-being", appearing in the titles of numerous scientific books, especially relating to business, education and management (quotation from Hallam, Ingold 2007: 2). The authors discuss two opposing conditions as ways to understand creativity which are imposed by specific cultural and historical conditions, namely: innovation and improvisation (2007: 1-24). The first one consists of identifying creativity with individuality, the breaking of social conventions, expression, and also with a radical rejection of the past. An identification such as this is a typical product of Western modernity, one that promotes individualism, one that gives a clear dichotomy of the social and individual as well as the positive valuation of the present, the future and change. It is aimed at effect and is not transparent. As Hallam and Ingold write:

According to these authors, the category of creativity should be widened significantly, and should not be identified withunconventionality but rather with improvisation. Improvisation does not have to mean deliberate, aimed at change, or a transgression of rules. It is the essence of every act, because there is no reproductively implemented scenario of cultural and social life (Hallam, Ingold 2007: 1). Each system of conventions only provides general guidelines that one should put into context and adapt to 
a particular situation which is always unique (Hallam, Ingold 2007: 2). The identification of creativity and improvisation as stipulated by the authors is undistinguishably about understanding creativity as a process: a kind of "happening" that goes on not so much in the mind of an individual but in the mutual interaction between things endowed with agency, people and the environment. It allows one to see the creative potential in such inconspicuous activities like walking on a crowded street, or, to focus on the practices of writing, filling in official forms, tax returns or workbooks.

Adherence to these methodological demands leads to many consequences. One of those is the possibility of dethroning the modern institution of literature, to deprive it of a monopoly in the field of literate creativity (Karpowicz 2012: 36-49). Another consequence is a deeper, anthropological problematization of the categories such as text and writing, which are still largely seen as a reflection on literature understood in a modern way, yet criticized by Ingold.

By focusing on the concept of writing,for example in the culture of ancient Greece the verb graphein originally meant scraping letters, the word associated with writing is not so much an intellectual activity but a physical activity which required a great amount of effort to work, using a sharp tool with tough materials. (Harris 1986: 29). Similarly, in ancient Egypt, where the occupation of a writer or a scribe was contrasted with the occupation of a farmer or a craftsman, not because it was identified with that of an artist, but as a labor less physically tiring, cleaner and giving more social advantages (Kuckenburg 2006: 210).

Similar relativization can be applied to the category of text, whose cultural and historical concretizations do not come under one particular definition (Majewski 2013: 31-32). Apart from the fact that the category relates us to so many different artifacts such as literary texts, recipes, tombstone inscriptions or spontaneous writings on a wall, one should remember that for many centuries and in many institutional and cultural contexts texts were usually heard collectively in a controlled way rather than read silently by a single and relatively free reader. They were not subjected to a more or less arbitrary process of interpretation. They were rather subjected to memorizing, and to the internalization of patterns and values that they comprised of. For example, in the time of Plato, materials for learning how to read and write the first strings of letters were pieces of classical poetry. Reading those had nothing in common with interpretation as in today's school meaning, which is a reconstruction of an authorial intention accompanying the text and nor with a more modern, though originating in medieval biblical hermeneutics, way of reading (Olson 2011). Text primarily 
served at moralizing aims, while simultaneously being an accumulation of positive patterns (Ford 2003: 26).

Despite the late-modern discourse which associates writing as a free activity, in particular with a process which is not so much physical as mental, and one which consists of the direct externalization of thoughts on to paper, writing in ancient Greece was accompanied by completely different connotations. Writing was often associated as an activity that was not only physical, but also and most of all, socially disciplining. Writing did not involve creation in silent thought but specified, subsequently externalized contents, which comprised of physically reproducing ready-made graphical forms. Traces of this way of thinking can be found in Plato's Protagoras, where he compares state law enforcement with enforcing a line that a teacher sketches on a plate for a child who is learning how to write its first letters. The link between the requirements of the law and the letters written by a teacher, letters which the child does not write by himself but which he copies with his own hands and the accompanying note, stating that "he who transgresses them, is to be corrected ", are quite significant (Plato's Protagoras: 326e). Plotting the first letter is clearly opposed to the concept of free artistic and intellectual activities and identified with the disciplining reproduction of an imposed pattern. Needless to say, that this way of understanding writing is positively valued by Plato. Identifying it with a style of life would have been, for Plato, not only incomprehensible, but simply disastrous.

Therefore, the idea of writing as creating in silent thought and a freely chosen lifestyle is a fruit of modernity. Evidently the historical and cultural reasons for this are complex. Firstly, the identification of writing as primarily a mental activity, with direct conversation with one's own mind transferred to paper, was, at least in part, the result of a specified conception in order to facilitate writing, namelystationery which reduced the physical act of writing in order to benefit intellectual activities. It should be kept in mind that writing in ancient times was quite hard work, requiring not only the drafting of letters on parchment, a resistant material, but also scraping and smoothing the latter (Ingold 2007: 142-143). Thus, in the time of Thomas Aquinas intellectual creation was rather associated with speaking/dictating than with standalone writing; a noteworthy example of the fact is Summa, being dictated by him.

Additionally, the concept of writing understood as creativity required a particular concept of text, based on the assumption that the latter is a representation of an individual mind, not memory support; such a concept reached its apogee in the modern age (Olson 2011: 273-293). In the 
days of Plato reading and writing were not activities involved with the reproduction of texts as external and independent media. It was a way of creating and reconstructing supports for memory, which means that they were to be, under the attention of authority, internalized, and used later in various social and political contexts associated with oral communication oriented at the community of polis and its moral bonds (Ford 2003: 25-26). The concept of text as a representation required the development of their own graphic and semantic devices allowing independently, and therefore in the absence of its author and the institutions responsible for the "correct" understanding, to interpret a text in terms of its illocutionary power. This is associated with Walter J. Ong's observations that writing a text that "speaks for itself" (Ong 2011: 131-132) was not present at the beginnings of literacy. Such an ideal would have required finding that writing is not at all a perfect tool for the representation of spoken language. Consequently it requires the invention of punctuation, a theory of mind accompanied by adequate vocabulary which signals the intentions of the author and a dictionary would be used containing verbs such as "assume", "doubt", "argue", " assume ", etc. (Olson 2011: 180).

The transition from the notion of a text as memory support to the notion of the latter as representation is clear enough, especially if we compare medieval and modern tracts. If the case is that medieval questiones retain agonic structure of medieval scholastic debates and vague references to other texts, it is not only a result of the form as such. There are a small number which are preserved, the manuscripts are without pagination and thus preven us from precisely locating citations. This is primarily the result of the fact that the participants of those discussions shared the same memory, that they had internalized those texts. Modern tracts have lost their agonic structure, since they are imitations of a process undergone in an individual's mind rather than a course of common conversation and include precise references to other texts: references possible in print culture only, but also caused by the fact that a writer and a reader do not share any common memory. They are organized in a way that is proof of following the idea of a text understood as a representation, a text made for analytical, independent reading, meaningful in the absence of the author and any institutionalized interpretative community. Therefore a paradigmatic contemporary tract, Spinoza's Ethics, Demonstrated in Geometrical Order, begins with the definition of basic concepts and axioms supporting further reasoning and then a series of statements accompanied by evidence, possible explanations and footnotes that support the reading of the main text. It is no coincidence that it also contains many references intrinsic to the 
text, providing the reader with detailed ways enabling them to navigate independently through the text. Thus the text is understood as the result of "creative" activity and exceeds the tradition of single minded labour.

It is worth noting that the modern identification of writing as individualistic, or rather understood as innovative, unfolding along the lines of creation and ultimately alongside lifestyle was related to the democratization of literacy. In the Middle Ages, when literacy was basically a monopoly of the clergy, serving mainly the dominant institutions such as the church or the state, it could not become a tool of individual expression. Of course, the aforementioned democratization cannot be explained exclusively by the emergence of print and individualism as a modern value. It cannot be explained even by the emergence, in the eighteenth and nineteenth centuries, of public literate education and this is because: firstly, in every European country literate education is often accompanied by other assumptions and values (Graff 1987b), and secondly, not always and not everywhere did democratization meant the concept of, as was already rasied herein as, writing as creativeness. For example, a very high level of literacy in eighteenth century Sweden certainly related to its democratization, the latter, however, did not entail any democratization of writing as an act of individual expression. Such literacy was achieved in the context of religious, created for the needs of the Protestant church, general education. What was emphasized was not writing as an act of creating definitive texts, but selective and controlled reading (reading the catechism, the Bible). Moreover, this kind of reading, we should add, favored memorizing certain content, rather than interpretation (Chartier, 2007: 455).

Moreover, although the identification of writing as an individualistic, mental and creative activity, involving a crossing of a certain textual tradition, is of late-modern origins, it has never been a binding identification in all late-modern cultural institutions. A good illustration of the fact are today's early-school practices of writing and communing with text. School, as the main institution of literate initiation, including the first mass contact with literature, is an institution in which the practices of writing have been, for a relatively long time, rather closer to ritual operations (Holthoon von 2007: 439). In this case communing with the text here does not involve free, solitary and critical reading. It consists of shared, strongly established, subjected to interpretative control and re-reading (Olson 2009: 571-572).

Let us examine early-school literate practices. Before the act of writing becomes a tool to generate one's own independent content, it must be internalized. This first exercise, of a remarkably carnal quality, is not socially 
neutral. For it consists in associating the activity of writing with a number of cultural meanings as well as values and forming a culturally specific kind of perception. This training, left out of the classical theory of literacy and research on the social functioning of texts, is associated with certain, culturally specific ways of attention management. As such, it influences the organization of subsequent experience.

It should be noted that in the case of graphomotor exercises, writing does not have the character of intentional communication, nor is it a tool for individual expression or individual thought. It is, inherently, a bodily function, precisely: an originator of the body to specific gestures. These gestures, like the ritual ones, are not yet an instrument of consciously achieving by an individual their own particular purposes. And as such, they are not so much instrumental as symbolic and theybecomes expressions of belonging to the world of adults: a token of literary competence as determinants of power and knowledge. Of course, the use of a strong anthropological tradition of categories of ritual to graphomotor exercise requires some justification. More precisely, it requires extraction from a classical and fairly narrow understanding of ritual as a reproductive, reserved for the sacred, primitive communities and involving more or less a mechanically reproduced tradition and phenomenon. After all, in broader and more frequently used terms, for example by Eric Rothenbuhler (Rothenbuhler 2003), and in relation to the school by Peter McLaren (McLaren 1986), ritual may be secular, modern and creative. For collective action which consists of, depending on the specifics of a particular situation, adhering to certain collectively codified rules does not preclude creativity as improvisation. On the contrary, it is a necessary condition.

Of course, the difference between literacy school rituals and traditional rituals is that participants of the former are subject to continuous, individual evaluation. This evaluation, however, also has a symbolic character. The entire process of training preserves the ritual character, because child activities are not undertaken due to the calculation of measures and targets, but for the reason that others do so, and "one should do so" because of exactly the same reasons that cause ritual actions of the adults. Performed as a part of initial education writing exercises are collective practices, embedded in non-neutral time and space. They are difficult to interpret, if we focus only on the manner in which they exercise the body and mind of a single child. Writing consists in collective actions carried out simultaneously in socially structured and hierarchical, subjected to supervisory authority, space. They are performed in time centrally regulated by bells, more precisely, by the dual division of time (work / lesson 
versus rest / pause), characteristic of capitalist society. It is not identical with a style of life, with the form of action characteristic of the modern individualism. Like any given ritual it serves, to recall Peter McLaren's expression, "psychosocial integration" (McLaren 1986: 45), to be exact: providing individual mental and bodily activities with common meter associated with evoking a certain symbolic sphere. Like any ritual, writing, in this case, is standardized and repeatable, consistent with ready-made, arbitrarily fixed scenarios. Last but not least it is a kind of performance. In contrast to performance art, it is not about showing individual competence. It is rather a bond-creating action, collectively evoking atoken of belonging to a particular community.

Graphomotor exercises have yet another function. They serve as a particular type of social programming of perception, and hence programming a certain kind of experience. More importantly, this kind of programming does not involve "knowledge that": explicit knowledge, linguistically articulated and revised in subsequent, non-school individual development, knowledge which is provided by reading at a later stage of education. It concerns, to use Michael Polanyi's category, tacit knowledge: embodied and not disclosing in any form of explicitly expressed patterns or values. Knowledge, which affects our experience, although does not allow to shape the latter more or less freely.

One of the key elements of graphomotor exercises is the acquisition of skills needed for accurately reproducing templates of each of the letters printed on the start line of the workbook, and then independently imitated by a student. The method of acquiring this competence is not transparent, and what is interesting, it varies depending on the type of writing and the accompanying cultural area. For values preferred in the western, alphabet calligraphy, which is based on a certain kind of hand-eye coordination are, as Tim Ingold points out, constancy, stability and eye- centering.

It is clear when school Western calligraphy is compared with Chinese calligraphy. As in the latter, children learn to perform an ideogram performing the associated hand gesture in the air. These exercises in western schools are used only incidentally and much more difficulty is placed on the act of writing in motor, not visual, memory. In addition, classical Far Eastern calligraphy tracts teach that by observing things an excellent level of handwriting lines is possible to achieve. It is not aimed at modelling with a shape of an ideogram, a constant, enduring essence of the thing it denotes. The idea is to imitate with a hand gesture its mobility and volatility. This means that again, excellence in calligraphy is not a fixed formconnected to the product of writing. Intentional bodily expressions 
hidden behind, which seen from the point of view of western calligraphy is calligraphy that focuses on certain body disciplining, subordinated to the idea of visual precision and is something completely unnecessary (Ingold 2007: 131-136). From the point of view of the western literate initiation, Chinese calligraphers' words cited by Ingold, say how they attained perfection in performing certain ideograms by the gestural mimicking of the movement of flying birds, playing rats or a waterfall falling into the abyss seem completely incomprehensible (2007: 131-133). In western graphomotor activities a specific gesture itself is removed from the scope of intentional action. In contrast Far Eastern calligraphy becomes a transparent medium for producing/copying specific content, whilst in the previous one it is a non-transparent tool filled with content expression, and as such is subjected to intentional control and gradual improvement.

Of course, graphomotor exercises are hardly creative, if that term is to be reserved for innovative actions and understood in accordance with the modern and individualistic paradigm as criticized by Ingold. However, if we mean by creativeness improvisation, then we see that the performance of these exercises can be identified by creative adaptation to a specific situation and to the rules provided by an authority. As Hallam and Ingold write:

In writing with the pen, nothing the tip save the movement of the hand and fingers with their characteristic penhold. The line rendered on paper is the trace of an ongoing gestural improvisation. Though we may have been taught the "correct" ways to form letters by copying models, a person's handwriting is as distinctive and recognizable an aspect of their being, as it issues forth into the world, as is their voice. [...] The personal style is not planned or designed, but emerges through a history of improvisation, above all in finding ways to connect letters in the cursive script in the interest of speed and efficiency. In "joined -up" writing we fashion the joins, each in our own way, as we go along. (Hallam, Ingold 2007: 13)

Therefore the practices used in early school education, are practices of embodiment which can hardly be recognized as passive practices of reproduction. Although not a 'lifestyle', they remain a tool for creating and maintaining a particular social and perceptual experience.

In fact, insight into the specifics of the early-school literacy practices can not tell us what is writing as a specific cultural practice. On the contrary, it only allows us to problematize a number of his traditional definitions presented not only in Ong's and Ricoeur's writings, but also in popular thinking. There is, as I think, not one legitimate definition of writing, just as there is no single characteristic of his relationship with creativity, 
experience and individuality. There is rather a lot of literacy practices and its institutional contexts. Consequently, an understanding of the entire continuum of literacy policies and logics is waiting for the next generation of lieracy anthropologists.

\section{Bibliography}

Antropologia pisma. Od teorii do praktyki 2010, eds. P. Artières, P. Rodak, Warsaw: Wydawnictwa Uniwersytetu Warszawskiego.

Bańkowski Andrzej 2000, Etymologiczny Stownik Języka Polskiego, vol. 2, Warsaw: PWN.

Carruthers Mary J. 1990, The Book of Memory: The Study of Memory in Medieval Culture, Cambridge: Cambridge University Press.

Chartier Anne Marie 2009, The Teaching of Literacy Skills in Western Europe. An Historical Perspective, [in:] Cambridge Handbook of Literacy, ed. D. R. Olson, N. Torrance, Cambridge: Cambridge University Press.

Connerton Paul 2012, Jak społeczeństwa pamiętaja, trans. M. Napiórkowski, Warsaw: Wydawnictwa Uniwersytetu Warszawskiego.

Creativity and Cultural Improvisation 2006, eds. T. Ingold, E. Hallam, New York-Oxford: Berg.

Encyclopedia Britannica, "Writing", (http://www.britannica.com/search?query=writing, entered 20.02.14).

Ford Andrew 2003, Where Literacy Counts: Schooling, [in:] Writing Texts and the Rise of Literate Culture in Ancient Greece, ed. Y. Harvey, Cambridge: Cambridge University Press.

Godlewski Grzegorz 2008, Stowo - pismo - sztuka słowa. Perspektywy antropologiczne, Warsaw: Wydawnictwa Uniwersytetu Warszawskiego.

Goody Jack 2012, Mit, rytuat i oralność, trans. O. Kaczmarek, Warsaw: Wydawnictwa Uniwersytetu Warszawskiego.

Goody Jack 2011, Poskromienie myśli nieoswojonej, trans. M. Szuster, Warsaw: PIW.

Goody Jack, Watt Ian 2007, Następstwa piśmienności, trans. J. Jaworska, [in:] Almanach antropologiczny: oralnośćl piśmienność, eds. G. Godlewski, A. Karpowicz, I. Kurz, A. Mencwel, P. Rodak, Warsaw: Wydawnictwa Uniwersytetu Warszawskiego.

Goody Jack 2006, Logika pisma a organizacja społeczeństwa, trans. G. Godlewski, Warsaw: Wydawnictwa Uniwersytetu Warszawskiego.

Graff Harvey J. 1987, The Legacies of Literacy: Continuities and Contradictions in Western Culture and Society, Bloomington: Indiana University Press.

Graff Harvey J. 1979, Literacy Myth: Literacy and Social Structure in the Nineteenth Century City, New York: Academic Press.

Harris Roy 2009, Rationality and the Literate Mind, New York: Routledge.

Harris Roy 1986, The Origin of Writing, London: Duckworth.

Havelock Eric A. 2006, Muza uczy się pisać. Rozważania o oralności i piśmienności w kulturze Zachodu, trans. P. Majewski, Warsaw: Wydawnictwa Uniwersytetu Warszawskiego. 
Havelock Eric A. 2007, Przedmowa do Platona, tłum. P. Majewski, Warsaw: Wydawnictwa Uniwersytetu Warszawskiego.

Holthoon von Frits 2009, Literacy, Modernisation, Intellectual Community and Civil Society in Western World, [in:] Cambridge Handbook of Literacy, eds. D. R. Olson, N. Torrance, Cambridge: Cambridge University Press.

Ingold Tim 2007, Lines. A Brief History, Routledge, Taylor \& Francis Group, London, New York.

Ingold Tim 2000, The Perception of the Environment. Essays on Livelihood, Dwelling and Skill, London, New York: Routledge.

Karpowicz Agnieszka 2012, Proza życia. Mowa, pismo, literatura, Warsaw: Wydawnictwa Uniwersytetu Warszawskiego.

Kuckenburg Martin (2006), Pierwsze słowo: narodziny mowy i pisma, transl. B. Nowacki, PIW, Warszawa.

Leroi-Gourhan André 1964-65, Le geste et la parole, Paris: Albin Michel.

Majewski Paweł 2013, Pismo, tekst, literatura. Praktyki piśmienne starożytnych Greków i matryca pamięci kulturowej Europejczyków, Warsaw: Wydawnictwa Uniwersytetu Warszawskiego.

McLaren Peter 1986, Schooling as a Ritual Performance: Towards a Political Economy of Educational Symbols and Gesture, New York: Routledge \& Kegan Paul.

Olson David R. 2011, Papierowy świat. Pojęciowe i poznawcze implikacje piśmienności, trans. M. Rakoczy, Warsaw: Wydawnictwa Uniwersytetu Warszawskiego.

Olson David R. 2009, Literacy, Literacy Policy and the School, [in:] Cambridge Handbook of Literacy, eds. D. R. Olson, N. Torrance, Cambridge: Cambridge University Press.

Ong Walter J. 1991, Orality and Literacy. The Technologizing of the Word, London, New York: Routledge \& Kegan Paul.

Maty Stownik Jezyka Polskiego 1996, ed. E. Sobol, vol. 1, Warsaw: PWN.

Plato, Protagoras, http://www.gutenberg.org/files/1591/1591-h/1591-h.htm [entered: 20.02.14].

Ricoeur Paul 1976, Interpretation Theory: Discourse and the Surplus of Meaning, Fort Worth: Texas Christian University Press.

Rodak Paweł 2009, Pismo, ksiażka, lektura. Rozmowy: Le Goff, Chartier, Hebrard, Fabre, Lejeune, Warsaw: Wydawnictwa Uniwersytetu Warszawskiego.

Rothenbuhler Eric 2003, Komunikacja rytualna. Od rozmowy codziennej do ceremonii medialnej, trans. J. Barański, Cracow: Wydawnictwo Uniwersytetu Jagiellońskiego.

The National Literacy Campaignes. Historical and Comparative Perspectives 1987, eds. Harvey J. Graff, R. F. Arnove, New York: Springer.

Vandendorpe Christian 2008, Od papirusu do hipertekstu, Esej o przemianach tekstu i lektury, trans. A. Sawisz, Warsaw: Wydawnictwa Uniwersytetu Warszawskiego. 